Construction and Design Manual Museum Buildings

$\widehat{\widehat{ी}}$

DOM
publishers Edition DETAII 


\section{Museum Buildings}

Construction and Design Manual 


\section{Museum Buildings}

Construction and Design Manual

Hans Wolfgang Hoffmann

Edited by Christian Schittich

$\mathbf{A}_{\substack{\text { Dom } \\ \text { pubstres }}}^{\text {Edition DETAIL }}$ 